Conference Paper

\title{
The Effect of Corporate Governance on Investor Reaction in Mediation of Internet Financial Reporting
}

\author{
Faluthia Fitri Puspaningrum*, Hero Priono, Erna Sulistyowati, Muslimin, Sjarief Hidajat \\ Research Universitas Pembangunan Nasional “Veteran” Jawa Timur, Surabaya, Indonesia
}

*Corresponding author:

E-mail: faluthiafitri@gmail.com

\begin{abstract}
Internet Financial Reporting can help investors more quickly access company information as a basis for decision making. The sooner the information will make it easier for investors to react. Investor's reaction to information is indicated by a reaction to information that is valuable to investors, both good news or bad news. Corporate governance has developed as a reaction to various corporate failures as a result of bad corporate governance, so that information about corporate governance in the company can cause investor reactions, because the good or bad implementation of corporate governance in the company is one of the factors in decision makings, especially in investing in a company. This study aims to analyze and prove the effect of corporate governance on investor reaction mediated by internet financial reporting. The method used in this research is the quantitative method. The object of research used is companies included in Indonesia's Corporate Governance in collaboration with SWA magazine for the period 2013 - 2017. The population in this study is ninety-nine companies that are included in the Indonesian of Corporate Governance in collaboration with SWA magazine for the period of 2013 - 2017. To determine the research sample, the probability sampling method is used. The samples in this study were eight companies that were included in the Indonesia Most Trusted Company ranking in Indonesia's list of Corporate Governance in collaboration with SWA magazine for the period 2013-2017. Data collection techniques used were secondary data collection techniques, namely data obtained indirectly by studying documents related to research. Secondary data in the form of data on company financial statements included in Indonesia's of Corporate Governance in collaboration with SWA magazine for the period 2013 - 2017 published on the official website of the IDX. The analytical method used is Partial Least Square (PLS) which is assisted with Warp PLS 6.0 software. The results showed that Corporate Governance does not affect Internet Financial Reporting; Corporate Governance does not affect Investor Reaction; Internet Financial Reporting affect Investor Reaction, and Internet Financial Reporting does not mediate Corporate Governance to Investor Reactions.
\end{abstract}

Keywords: Corporate governance, investor reaction, and internet financial reporting

\section{Introduction}

Developments in the field of information technology affect changes to the way companies do business. The development of information technology is used to simplify all processes of company activities in running its business. The use of the internet in the business activities of the company can be transactions conducted via the Internet both money and information that is needed by the company (Andriyani \& Mudjiyani, 2017). According to Poon et al. (2003) states that the internet is an excellent medium for use as a means to accommodate the changes that are 
needed

in

corporate

reporting. Intern et developed into

a

medium that can convey information more effectively to the public. Media delivery of information financial is then known by the term Internet Financial Reporting or the usual abbreviated IFR. Internet Financial Reporting (IFR) arises because of the need on the part of investors to get company information more quickly and accurately. Internet Financial Reporting - IFR is expected to be able to improve company communication with stakeholders, especially investors. With the Internet Financial Reporting IFR, investors can more quickly access company financial information as a basis for decision making.

The reaction of investors to the information indicated by the change in the price of the stock which is measured by looking at the returns is not normal (abnormal returns). Abnormal return is one of the indicators used to see the current market condition (Hargyantoro. 2010; Gantyow \& Sulistiyani, 2008). In addition to seeing changes in stock prices, to see investors' reactions to an event can be seen from changes in stock trading volume. This is because the stock price in the secondary market will also be determined by the bargaining power of investors in the capital market (Restuningdiah, 2011).

Corporate governance has developed as a reaction to various corporate failures as a result of poor corporate governance. Corporate governance is corporate governance that explains the relationship between various parties with an interest in the management of the company in determining the direction of company performance (Abdillah, 2018; Darmawati, 2003). Implementation of the commitments Corporate Governance that is good or so-called Good Corporate Governance (GCG) is contained in the company's mission is to create powerful competitive to attract investors and issuers through the empowerment of exchange members and participants, creation of value-added, cost-efficiency and the implementation of good governance (Sulistyowati, 2018). The benefits from the implementation of good corporate governance can impact positively the creation of company accountability, a transaction that is fair and independent, as well as the reliability and improving the quality of information to the public. Based on the background that has been described by the researcher, the problem formulation in this study is as follows: (1) Does corporate governance affect investor reactions? (2) Does Corporate Governance affect Internet Financial Reporting? (3) Does Internet Financial Reporting affect Investor Reaction? (4) Does Internet Financial Reporting mediate Corporate Governance against Investor Reactions?

\section{Review the Library}

\section{Agency theory}

Agency theory has begun to grab the attention of the research world since the emergence of the journal by Jensen and Meckling (1979). The journal explains the theory that discusses the relationship (agency relationship) and agency problems (agency problems) between principals and agents. The relationship between the principal and the agent occurs when the principal as the owner of the company uses the services of an agent to manage the company and gives the agent authority to make decisions regarding the company's operations (Jehsen and Mecca, 1979). Apart from company owners, lenders (creditors) can become principals in agency theory.

\section{Signaling theorys}

The signal theory (signaling theory) was first put forward by Michael Spence. According to him, signal theory by providing a signal, the sender (owner of the information) tries to provide pieces of relevant information that can be used by the recipient. The receiving party will then adjust its behavior according to its understanding of the signal. Companies that have good prospects send clear and reliable signals to the market when they go public so that they can get a good response (Retno \& Priantinah, 2012). 


\section{Investor reaction}

Market reaction is a form of market response to the information contained in an announcement issued by a company. The announcements issued are considered by investors as a signal and information from management regarding the condition of the company. Investor reactions can be seen through an efficient market form, which is reflected in changes in stock prices (Gantyow \& Sulistiyani, 2003; Indra, 2013; Restuningdiah. 2011). The reaction of investors to information is shown by the change in stock prices as measured by the abnormal return. Abnormal return is an indicator used to see the current market condition. A policy will be valuable information for investors, both good news and bad news (Yuliana et al., 2008).

\section{Corporate governance}

Corporate governance can be interpreted as good governance. Corporate governance usually includes processes, customs, rules, and institutions that will ultimately influence policy and control of an organization, and includes the relationship between the perpetrator of companies such as management, investors, creditors, the board of directors, regulators, supplier, consumers, and society at large. Corporate governance describes the procedures for companies to be accountable to stakeholders. So companies that use corporate governance are expected to provide confidence to investors regarding the lawyer (return) on the funds invested or otherwise protect the interests of investors of agency problems (Darmawati, 2003; Sulistyowati, 2018). Almilia (2006) show that the announcement of the Corporate Governance Perception Index (CG PI) is reacted by the market, which is marked by abnormal returns and significant stock trading volume around the announcement date for both companies that are in the top ten and non-top ten CGPI. It was also found that dian tare the same group there was no difference in abnormal return and trading volume during the announcement of the CGPI. Although there is no difference between the two groups of companies because they are equally reacted, it does not mean that this ranking is useless, it can be said that this ranking is more meaningful for the issuer because by following this survey the listed companies will know better how good their corporate governance is so that if it is there is a drawback they can fix it immediately.

According to Dheasy (2013), company size does not have a significant effect on the presentation of corporate financial reporting via the internet. Companies with a large size that has a disclosure Internet Financial Reporting (IFR) which is the lowest index or that have disclosure of Internet Financial Reporting (IFR) which is the highest index do not affect the company's corporate governance.

H1: Corporate Governance affects Investor Reaction.

H2: Corporate Governance affects Internet Financial Reporting.

\section{Internet financial reporting}

Internet Financial Reporting can be defined as a method of distributing financial reports by using the internet or the company's official website as a medium (Ettredge et al., 2001; Poon et al., 2003; Marston, 2003). According to Indra (2013), it shows that there is an influence on the level of information disclosure of Internet Financial Reporting IFR on investor reactions. However, it did not prove that the scope of Internet Financial Reporting IFR disclosure affected the abnormal return of company stocks. The small percentage of interlinked websites of companies to website Indonesia Stock Exchange (BEI) can be a cause of variable scope of the disclosure of Internet Financial Reporting IFR did not affect abnormal stock returns. Furthermore, the test results of investors' reaction speed between companies with high disclosure levels of Internet Financial Reporting - IFR and companies with low disclosure levels of Internet Financial Reporting - IFR, showed no significant difference.

The information content required by investors from the company website format is considered more relevant than the presentation format (Xiao et al., 2004). The speed of delivery of internet financial reporting is influenced by the corporate governance mechanism. Perus Ahaan 
has a mechanism of corporate governance that will better promote the interests of investors and creditors relating to financial information. The disclosure of the quality of internet financial reporting can be used as an improvement in the effectiveness of manager monitoring. To achieve transparency and accountability, companies will submit their financial reports properly. Therefore the corporate governance mechanism has a positive influence on the speed of delivery of internet financial reporting. Investors or potential investors tend to look for companies that have good or high corporate governance ratings because it indicates that the company has implemented good corporate governance. Investors or potential investors have more confidence in companies that implement good corporate governance because they are more transparent. This makes investors willing to give more premium to company shares (Retno \& Priantinah, 2012).

H3: Internet Financial Reporting does not affect Investor Reaction.

H4: Internet Financial Reporting Mediates the Effect of Corporate Governance on Investor Reactions

\section{Material and Methods \\ Population and sample}

In this study, the population used is the company that is included in the ranking of The Indonesia Most Trusted Company published by SWA magazine, totaling 99 companies. The selection of the observation period was based on the application of the Corporate Governance Award which began in 2013-2 017. The sampling technique used was probability sampling, so that 8 companies met the sample criteria with 5 years of observation (2013 - 2017), namely companies that were listed in Indonesia's Most Trusted Company.

\section{Types and sources of data}

The type of data used in this study is secondary data, namely a financial report taken from the Indonesia Stock Exchange from 2013 - 2017. The data source used in this study is a secondary source, which is obtained by SWA Magazine to retrieve or collect data about the ranking of The Most Trusted Indonesia Company as well as manufacturing company websites listed on the IDX from 2013 - 2017.

\section{Variable measurement}

Corporate governance

The definition of corporate governance, in general, is a set of rules in a company that regulates the relationship between agency and principal to improve company operations so that they can provide added value to shareholders. In this study, corporate governance is a ranking of the compliance of companies in implementing corporate governance as measured by the Corporate Governance Perception Index. The Corporate Governance Perception Index is issued by the Indonesian Institute of Corporate Governance in collaboration with SWA magazine. The assessment of the Corporate Governance Perception Index includes four categories, namely:

a. Self-assessment (by 15\%)

b. Completeness of documents ( $25 \%)$

c. Papers and percentages (12\%)

d. Observation (by $48 \%$ )

For companies that get the Corporate Governance Perception Index to score up to 69.99, the company has a fairly reliable predicate. For companies that get a score of 70 to 84.99 then the company has the title of being trusted. Companies that get a score of 85 to 100 have the predicate of being very trusted.

\section{Internet financial reporting}

Internet Financial Reporting can be defined as a method of distributing financial reports using the internet or the company's official website as the medium. Internet Financial Reporting 
is measured by looking at the publication date of the internet financial reporting. Each company is required to publish an audited annual financial report no later than 120 days or 4 months from the end of the financial year. This regulation is following Law no.8 of 1995 and Kep No. 80 / PM / 1996 which was issued by BAPPEPAM-LK. Thus, the speed of delivery of Internet Financial Reporting is measured by calculating the difference from the expiry date of the delivery of Internet financial reporting reduced to the date of delivery of Internet financial reporting. More details are illustrated by the following image:

31 December (closed-book)

\author{
31Jamuary \\ (Submission IFR)
}

30 April
(deadline final IFR submission)

Figure 1. The speed of delivery of internet financial reporting

\section{Investor Reactions}

Market reaction is a form of market response to the information contained in an announcement issued by a company. The announcement issued by investors is considered by investors as a signal and information from management regarding the condition of the company. Investors' reactions can be seen through an efficient market form, which is reflected in changes in share prices.

Abnormal return is the dependent variable that is measured by setting aside the actual return that occurs with the expected return (Hartono, 2015). This study uses a market-adjusted model to estimate the expected return.

a. Calculating return actually ( actual return ) of each sample by the formula:

Rit $=\frac{P t-P t-1}{P t-1}$

Information:

Rit: Individual return of shares i at $\mathrm{t}$

Pt: closing price of shares i at $t$

$P t-1$ : closing price of shares i at $\mathrm{t}-1$

b. Calculating return expectations ( expected return ) each sampeldengan formula:

$R m t=\frac{I H S G t-I H S G t-1}{I H S G t-1}$

Information:

$R m t$ : The market rate of return at time $\mathrm{t}$

IHSGt : Composite Stock Price Index at time t

IHSGt-1: Composite Stock Price Index at t-1

c. Calculating the abnormal return for each sample with the formula:

$A R i t=R_{i t}-R m t$

Information:

ARit : Abnormal return of stock i at time $\mathrm{t}$

$R$ it : Return of individual stock i at time $\mathrm{t}$

$R m t$ : Rate of return of stock at time $\mathrm{t}$ 
d. Calculating Cumulative Abnormal Return, namely:

CARit $=t=5$ ARit

$E$
$a=t 1$

Information:

CARit: Cumulative Abnormal Return of the company to period $\mathrm{t}$, which is accumulated from the securities ARit $\mathrm{i}$, the period of events before ( $\mathrm{t}-5)$ to $(\mathrm{t}-1)$, and the period of events after $(t+1)$ to $(t+5)$.

\section{Data analysis technique}

Data analysis techniques and hypothesis testing in this study used data analysis in this study using partial least square (PLS), assisted by software WarpPLS 6.0. Hypothesis testing is based on the path coefficient and the total effect of the research variables. Significance testing was carried out using the bootstrapping method. The mediation effect assessment criteria are based on the VAF value.

\section{Results and Discussion Outer model test}

Two criteria for assessing whether the outer model meets the convergent validity requirements for a reflective construct, namely: (1) loading must be above 0.70 and (2) the pvalue is significant $(<0.05)$ (Hair et al., 2013). The outer model in this study can be described as follows:

Table 1. Output structural loading s and cross-loadings

\begin{tabular}{cccc}
\hline & CG & IFR & RI \\
\hline CG & 1,000 & 0.000 & $-0,000$ \\
IFR & $-0,000$ & 1,000 & -0.386 \\
RI & 0.000 & -0.386 & 1,000 \\
\hline
\end{tabular}

Table 2. Summary of outer test results - output combined loadings and cross-loadings

\begin{tabular}{llllll}
\hline & CG & IFR & RI & Type (a SE & P value \\
\hline CG & 1,000 & 0.000 & $-0,000$ & Reflect 0.103 & $<0.001$ \\
IFR & $-0,000$ & 1,000 & 0.000 & Reflect 0.103 & $<0.001$ \\
RI & $-0,000$ & 0.000 & 1,000 & Reflect 0.103 & $<0.001$ \\
\hline
\end{tabular}

Based on table 1 and table 2, shows that the results of cross-loadings have met discriminant validity because they have a cross-loadings value that must be above 0.50 . Thus all the variables in this study have met the discriminant validity (outer model).

The corporate governance indicator has a greater loading on the corporate governance construct of 1,000. cross-loadings to the Internet Financial Reporting construct of 0,000 and investor reaction to $-0,000$ lower than the construct of corporate governance. The results of these cross-loadings can be an indication of the fulfillment of the discriminant validity criteria.

\section{Hypothesis statistical test}

The data analysis of this research used party least square (PLS), assisted by the WarpPLS 6.0 software. The path analysis model of all latent variables in the PLS of this study consists of two stages, namely estimating the direct effect and estimating the indirect effect simultaneously with the SEM model triage. The following are the results of hypothesis testing. 


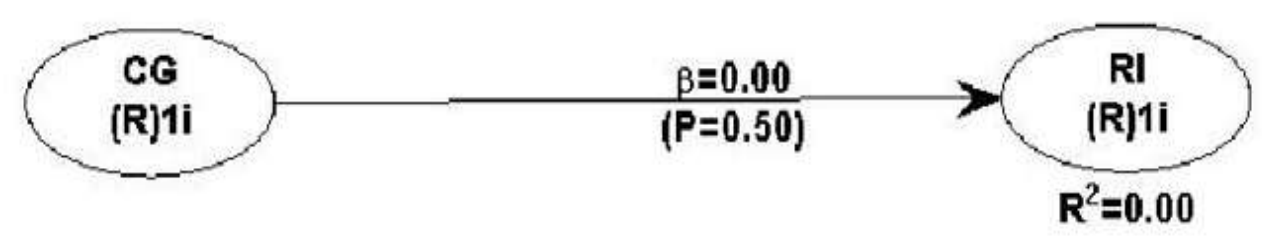

Figure 2. Direct Effect Model Source: IDX data (processed data)

Figure 2 shows that the estimation of Corporate Governance (hereinafter referred to as CG) has a direct effect on Investor Reactions (hereinafter referred to as RI) is 0.00 and with a significance value of $\mathrm{p}=0.50$.

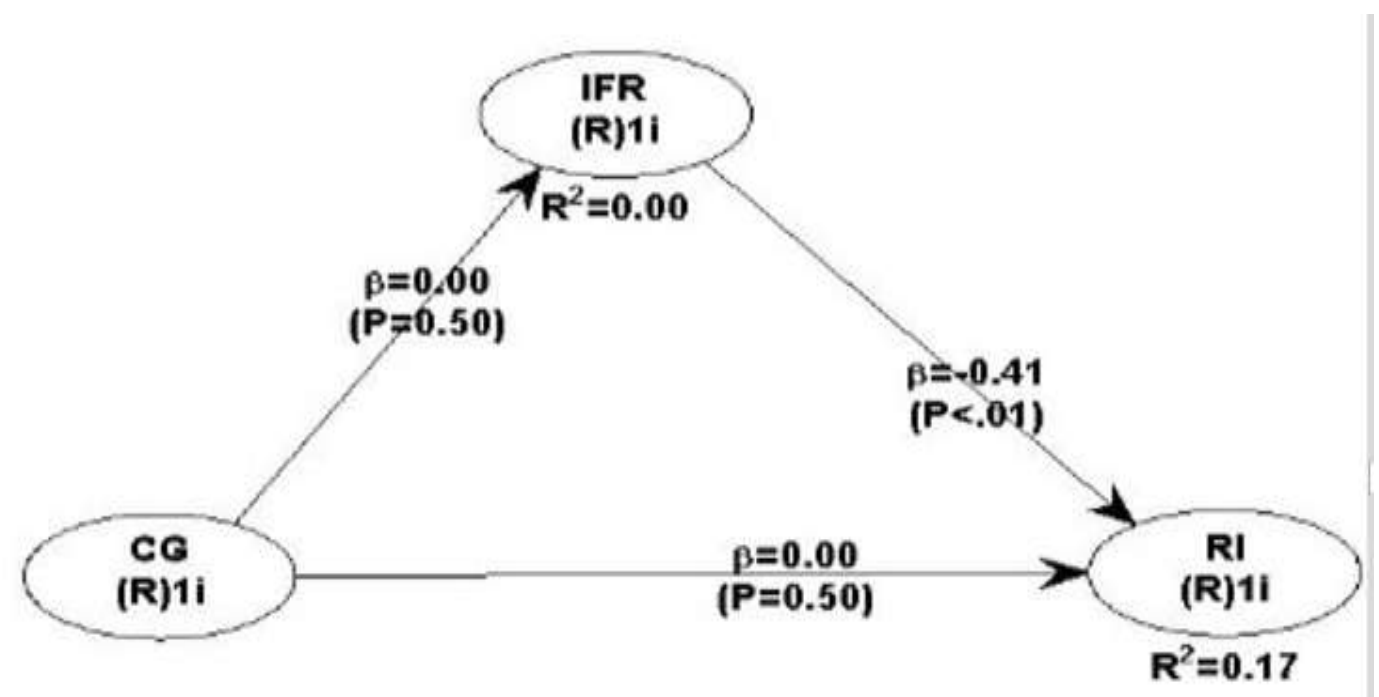

Figure 3. Indirect effect model (Source: IDX data - processed data)

Figure 3 shows that the estimation of CG has no effect on Internet Financial Reporting (hereinafter referred to as IFR) is 0.00 and is not significant with a significant value of $p=0.50$. IFR affects RI is -0.41 and with a significant value i $\mathrm{p}<0.01$. The direct effect estimation results simultaneously with the triangle SEM model, namely CG to RI through IFR, namely the direct effect estimation path coefficient is fixed and insignificant, so the mediation hypothesis is not supported.

\section{Conclusion}

1. Corporate Governance does not affect Internet Financial Reporting.

2. Corporate Governance does not affect Investor Reaction.

3. Internet Financial Reporting affect Investor Reaction.

4. Internet Financial Reporting does not mediate Corporate Governance towards Investor Reactions.

\section{References}

Abdillah, M., \& Ridwan. (2018). Corporate governance and company value with internet financial reporting as an intervening variable. Journal of Economics and Business, 11(2), 281-299.

Almilia, L. S. (2008). Factors affecting the voluntary disclosure of "internet financial and sustainability reporting . JAAI, $12(2), 117$ 131. 
Andriyani, R., \& Mudjiyani, R. (2017). The effect of profitability, leverage, number of independent commissioners and institutional ownership on Internet Financial Reporting (IFR) disclosures on the Indonesia Stock Exchange. Kom Partemen, XV(1), 1-5.

Darmawati, D. (2003). Corporate governance and earnings management: An empirical study. Journal of Business and Accounting, 5(1), 47-68.

Dheasy, R. (2013). Analysis of factors affecting the financial reporting index via the internet . Journal of Accounting and Financial Review, 3(1), 1-5.

Ettredge, M., Richardson, V. J., \& Scholz, S. (2001). The presentation of financial information at corporate web sites. International Journal of Accounting Information Systems, 2, 149-168.

Gantyow, E, \& Sulistiyani, Y. (2008). Reaksi against markets dividend announcement the company's corporate governance perception index sign . Journal of Business And Accounting, 10(3), 161-71. https://doi.org/10.34208/jba.v10i3.247.

Hair, J. F., Black, W. C., Babin, B. J., \& Anderson, R. E. (2009). Multivariate data analysis, (7th Ed.) , New Jersey: Pearson.

Hargyantoro, F. (2010). The influence of internet financial reporting and website information disclosure level on company stock trading frequency. Faculty of Economics. Diponegoro University Semarang.

Hartono, J. (2015). Portfolio theory and investment analysis edition 10 . Yogyakarta: BPFE Yogyakarta.

Indra, W. (2013). Investor reactions to internet financial reporting disclosures. Journal of Accounting and Financial Review, 3(2), 1-5.

Jensen, M. C.,\& Meckling, W. H. (1979). Theory of the firm. Managerial Behavior, Agency Costs, And Ownership Structure: Springer.

Marston, C. (2003). Financial reporting on the internet by leading japanese companies. Corporate Communications: An International Journal, 8(1), 23-24.

Poon, P., Li, D., \& Yu, YT. (2003). Internet financial reporting. Information System Control Journal, 1(3), 1-5.

Restuningdiah, N. (2011). Income smoothing against market reaction using GCG mechanism and CSR Disclosure . Integrity - Journal of Business Management, 3(3), 235-240.

Retno, R. D., \& Priantinah, D. (2012). Influence of good corporate governance and disclosure of corporate social responsibility on firm's value (Empirical study of companies listed on the indonesia stock exchange 2007-2010) . Nominal Journal, 1(1), 20.

Sulistyowati, E. (2018). The influence of corporate governance social responsibility and intellectual capital on firm's value mediated by internet financial reporting timeliness. Thesis Dissertation, Airlangga University.

Xiao, J. Z., Yang, H., \& Chow, C. W. (2004). The determinants and characteristics of voluntary internet based disclosure by listed chinese companies. Journal of Accounting and Public Policy, 23, 191-225.

Yuliana, R, Purnomosidhi, B., \& Eko, G. S. O. (2008). The effect of company characteristics on disclosure of Corporate Social Responsibility (CSR) and its Impact on Investor Reactions . Indonesian Journal of Accounting and Finance, 5(2), 245-276. 